\begin{tabular}{|c|c|c|c|c|c|c|c|c|}
\hline \multicolumn{3}{|c|}{$\begin{array}{l}\text { 2. To: (Recoiving Organization) } \\
\text { CHG Characterization Engineering }\end{array}$} & \multicolumn{2}{|c|}{$\begin{array}{l}\text { 3. From: (Originating Organization) } \\
\text { Characterization Engineөring }\end{array}$} & \multicolumn{4}{|c|}{$\begin{array}{l}\text { 4. Related EDT No.: } \\
\text { N/A }\end{array}$} \\
\hline \multicolumn{3}{|c|}{$\begin{array}{l}\text { 5. Proj.Prog/Dept/Div.: } \\
\text { Characterization Project }\end{array}$} & \multicolumn{2}{|c|}{$\begin{array}{l}\text { 6. Design Authority/ Design Agent/Cog. } \\
\text { RN Dale/CG Linschooten/TR Farris }\end{array}$} & \multicolumn{4}{|c|}{$\begin{array}{r}\text { 7. Purchase Order No.: } \\
\text { NA }\end{array}$} \\
\hline \multirow{2}{*}{\multicolumn{5}{|c|}{$\begin{array}{l}\text { 8. Originator Remarks: } \\
\text { Supporting document submitted for review and approval prior to release } \\
\text { This document encompasses the ETP, Functional Design Requirements and ABU. }\end{array}$}} & \multicolumn{4}{|c|}{$\begin{array}{l}\text { 9. Equip/Component No.: } \\
\qquad \text { N/A }\end{array}$} \\
\hline & & & & & \multicolumn{4}{|c|}{$\begin{array}{r}\text { 10. System/BIdg./Facility: } \\
200 \mathrm{G}\end{array}$} \\
\hline \multirow{3}{*}{\multicolumn{3}{|c|}{$\begin{array}{l}\text { 11. Receiver Remarks: } \\
\text { ETN-99-0009 }\end{array}$}} & \multirow{3}{*}{\multicolumn{2}{|c|}{ o Document? [X] Yes D No }} & \multicolumn{4}{|c|}{$\begin{array}{l}\text { 12. Major Assm. Dwg. No.: } \\
\text { N/A }\end{array}$} \\
\hline & & & & & \multicolumn{4}{|c|}{$\begin{array}{l}\text { 13. Permit/Permit Application No.: } \\
\text { N/A }\end{array}$} \\
\hline & & & & & \multicolumn{4}{|c|}{$\begin{array}{l}\text { 14. Required Response Date: } \\
\text { ASAP }\end{array}$} \\
\hline 15. & \multicolumn{4}{|c|}{ DATA TRANSMITTED } & (F) & (G) & (H) & (I) \\
\hline $\begin{array}{l}\text { (A) } \\
\text { ltem } \\
\text { No. }\end{array}$ & (B) Document Drewing $\mathrm{No}$. & $\begin{array}{l}\text { (C) } \\
\text { Sheet } \\
\text { No. }\end{array}$ & $\begin{array}{l}\text { (D) } \\
\text { Rov. } \\
\text { No. }\end{array}$ & (E) Titb of Description of Data Trensmittod & $\begin{array}{l}\text { Apporoval } \\
\text { Dosig- } \\
\text { neltor }\end{array}$ & $\begin{array}{l}\text { Reeson for } \\
\text { Trens:- } \\
\text { mittal }\end{array}$ & $\begin{array}{l}\text { Origi- } \\
\text { nator } \\
\text { Dispo- } \\
\text { stion }\end{array}$ & $\begin{array}{l}\text { Receiv- } \\
\text { of } \\
\text { Dispo- } \\
\text { sition }\end{array}$ \\
\hline 1 & RPP-6134 & NA & 0 & $\begin{array}{l}\text { ENGINEERING TASK PLAN FOR } \\
\text { WATER SUPPLY FOR RMCS } \\
\text { SPRAY WASH TRAILER. }\end{array}$ & $S / Q$ & 1 & 1 & \\
\hline
\end{tabular}

\begin{tabular}{|c|c|c|c|c|c|c|c|}
\hline \multicolumn{8}{|c|}{$\overline{\text { KEY }}$} \\
\hline \multicolumn{3}{|c|}{ Approvel Designetor (F) } & \multicolumn{3}{|c|}{ Reeson for Trensmittal (G) } & \multicolumn{2}{|r|}{ Disposition $(H) \&(U)$} \\
\hline \multicolumn{2}{|c|}{$\begin{array}{l}\text { E, S, Q, DorNA } \\
\text { (see WHG-CM-3.5, } \\
\text { Soc.12.7) }\end{array}$} & & $\begin{array}{l}\text { 1. Approvel } \\
\text { 2. Rebeses } \\
\text { 3. Information }\end{array}$ & \multicolumn{2}{|l|}{$\begin{array}{l}\text { 4. Reviow } \\
\text { 5. Post-Reviow } \\
\text { 6. Dist. (Rocoiph Acknow. Requirod) }\end{array}$} & \multicolumn{2}{|c|}{ 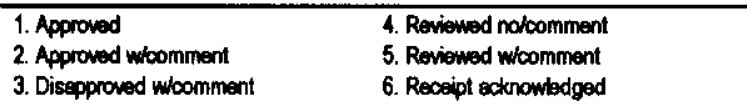 } \\
\hline \multicolumn{8}{|c|}{ SIGMATUREDISTRIBUTION } \\
\hline \multicolumn{8}{|c|}{ (See Approval Designator for required signetures) } \\
\hline $\begin{array}{l}\text { (G) } \\
\text { Reat } \\
\text { Son }\end{array}$ & $\begin{array}{l}\text { (H) } \\
\text { Disp. }\end{array}$ & & Namo & Wure (L) Date (M) MSIN & $\begin{array}{l}\text { (G) } \\
\text { Rest } \\
\operatorname{son}\end{array}$ & $\begin{array}{l}(H) \\
\text { Disp. }\end{array}$ & $\begin{array}{lll}\text { (K) Signeture } & \text { (L) Date (M) MSIN }\end{array}$ \\
\hline 1 & 1 & Desig & hority RN D & $657-12$ & 1 & 1 & $-4 / A / O 7-12$ \\
\hline 1 & 1 & Desig & int CG Linse & $=37-12$ & $\overline{1}$ & 1 & JSLee \\
\hline 1 & 1 & $\operatorname{Cog} . E$ & R Farris & $70657-12$ & 1 & 1 & $1 / 18 / 00^{57-12}$ \\
\hline 1 & 1 & $\operatorname{Cog} .1$ & Schofi & $57-12$ & 1 & 1 & $41057-03$ \\
\hline 1 & 1 & QA N & Elror $\mathrm{H}$. & $4 / / 8 / \infty 87-07$ & 1 & 1 & GW Wilson GMYMh \\
\hline \multirow[t]{2}{*}{9} & 1 & Safety & Jackson &  & & & \\
\hline & & Env. & & & & & \\
\hline
\end{tabular}

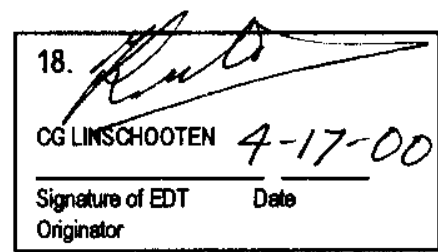

BD-7400-172-2 (05/96) GEF097
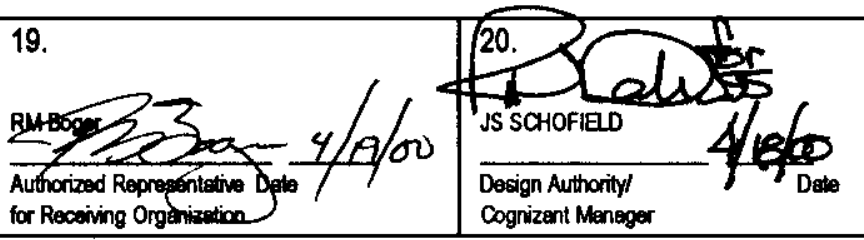

\section{DOE APPROVAL (if required) \\ Ctri. No. \\ [ Approved \\ प Approved w/comments \\ [ Disapproved w/comments}




\section{ENGINEERING TASK PLAN FOR WATER SUPPLY FOR RMCS SPRAY WASH TRAILER}

R.M. Boger

Prepared by CH2M HILL Hanford Group, Inc.

Richland, WA 99352

U.S. Department of Energy Contract DE-AC06-9918/:14047

EDT/ECN: 628745

UC: 2000

Org Code: 74900

B\&R Code: EW313000

Charge Code: 102206ES10

Total Pages: 17

Key Words: RMCS, SUPPORT TRUCKS, WATER SUPPLY, TRAILER, DRILL ROD, SPRAY WASHERS, TANK FARM, CHARACTERIZATION RROJECT, ETN-99-0009.

Abstract: This ETP defines the task and deliverables associated with the design, fabrication and testing of an improved spray wash system for the Rotary Mode Core Sampling (RMCS) Spray Wash Trailer.

TRADEMARK DISCLAIMER. Reference herein to any specific commercial product, process, or service by trade name, trademark, manufacturer, or otherwise, does not necessarily constitute or imply its endorsement, recommendation, or favoring by the United States Government or any agency thereof or its contractors or subcontractors.

Printed in the United States of America. To obtain copies of this document, contact: Document Control Services, P.O. Box 950, Mailstop H6-08, Richland WA 99352, Phone (509) 372-2420; Fax (509) 376-4989.
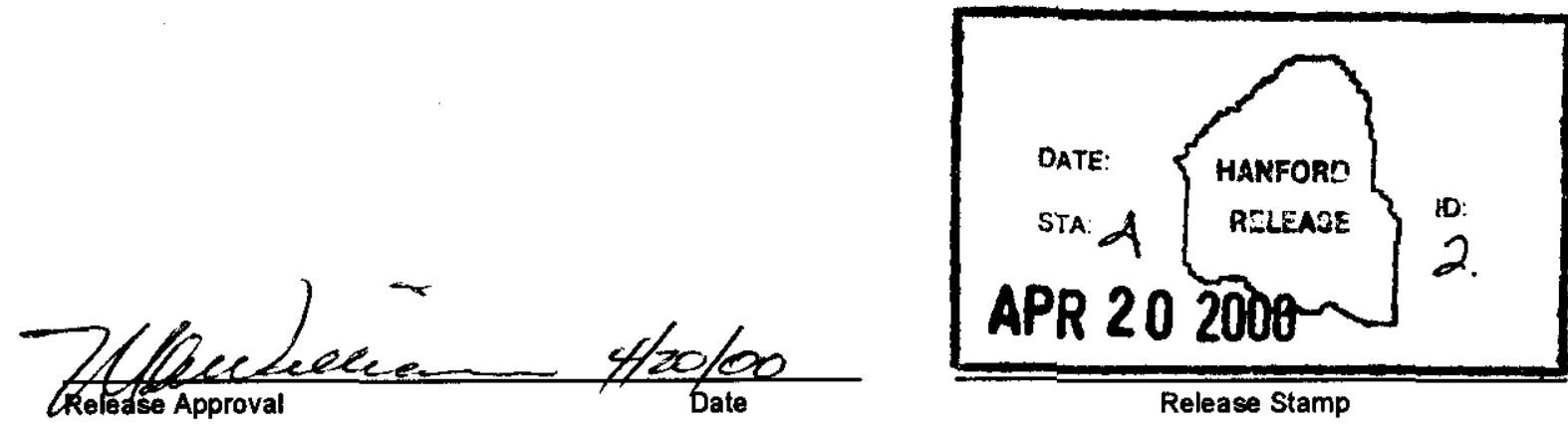

Release Stamp 


\title{
ENGINEERING TASK PLAN FOR WATER SUPPLY FOR RMCS SPRAY WASH TRAILER
}

\author{
Characterization Engineering \\ River Protection Project \\ CH2M HILL Hanford Group, Inc. \\ Richland, Washington \\ Prepared by \\ C. G. Linschooten \\ Numatec Hanford Corporation \\ Richland, Washington
}

April 2000 
Table of Contents

2.0 SCOPE 1

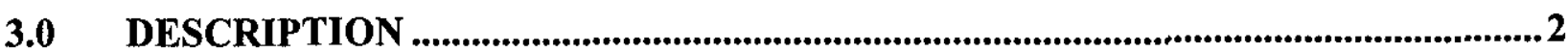

3.1 PHYSICAL DESCRIPTION......................................................................................2

3.1.1 SPRAY WASH SYSTEM...........................................................................

3.2 DESIGN REQUIREMENTS ........................................................................................2

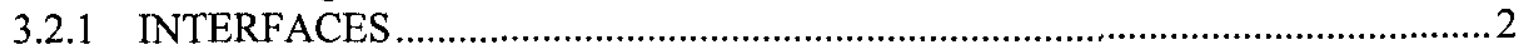

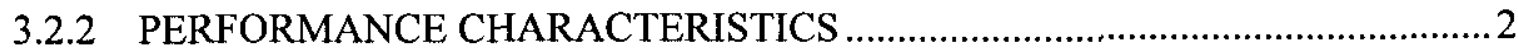

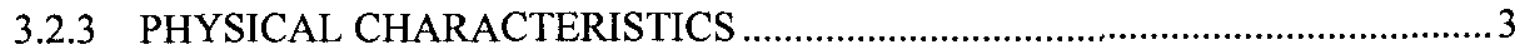







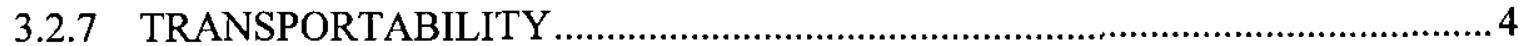

3.3 ENGINEERING TASKS.............................................................................................4



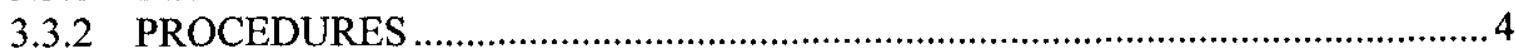



3.4 DESIGN VERIFICATION.......................................................................................5

3.5 PROCUREMENT/FABRICATION TASKS.................................................................5

INSTALLATION TASKS .........................................................................................5

3.7 PRE-OPERATIONAL AND OPERATIONAL TESTS...............................................5

3.8 ACCEPTANCE FOR BENEFICIAL USE ........................................................................5

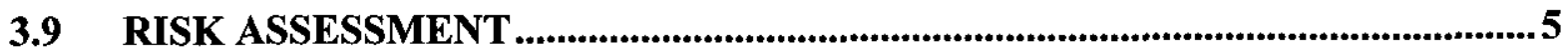

4.0 ORGANIZATION

4.1 CHARACTERIZATION FIELD ENGINEERING (CFE) .....................................5

4.2 CHARACTERIZATION ENGINEERING ....................................................................5

4.3 CHARACTERIZATION PROJECT OPERATIONS..................................................6

4.4 QUALITY ASSURANCE AND SAFETY .................................................................6 


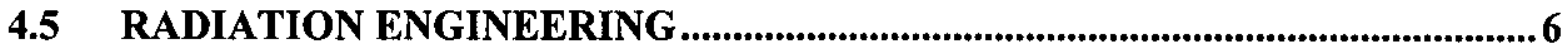

4.6 FLAMMABLE GAS EQUIPMENT ADVISORY BOARD ....................................6

5.0 SCHEDULE AND COST ESTIMATE ..................................................................................6

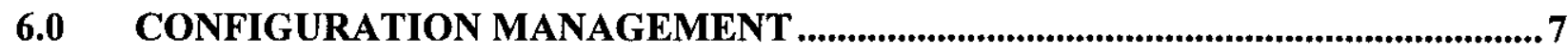

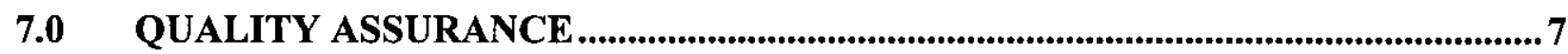

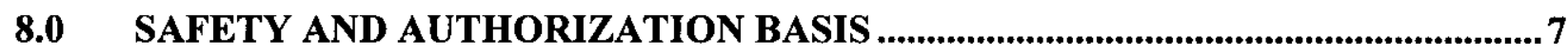

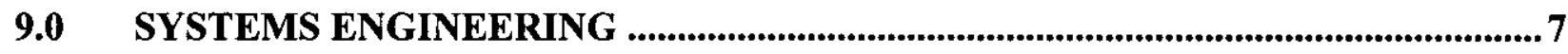

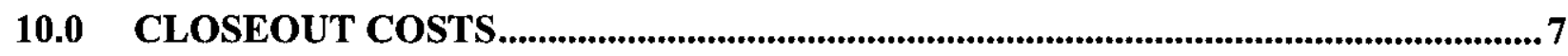

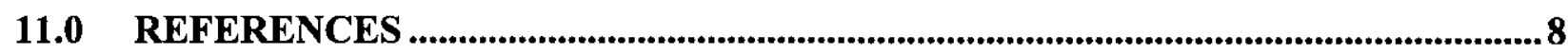

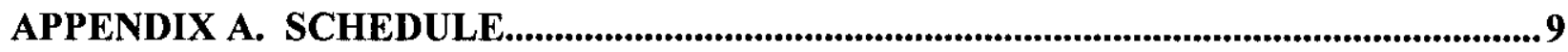

APPENDIX B. COLD WEATHER OPERATING PARAMETERS AND DESIGN CONSIDERATIONS.............................................................................................................................11

APPENDIX C. ACCEPTANCE FOR BENEFICIAL USE............................................12 


\section{ENGINEERING TASK PLAN FOR WATER SUPPLY FOR RMCS SPRAY WASH TRAILER}

\subsection{INTRODUCTION}

When the drillstring and sampling equipment is removed from waste storage tanks by the core drilling truck, the components are washed. Washing is performed with one of five spray washers depending upon the component being removed:

1. The Cable Spray Washer item number H-2-690134-11 (LMHC 1996) cleans the sampler hoist cable as it is withdrawn from the drillstring carrying the Remote Latch Unit (RLU) and sampler. It also cleans the grapple hoist cable as it is withdrawn from the drillstring carrying the pintle rod and grapple. The Cable Spray Washer washing fluid is supplied at a maximum pressure of 500 psig ( 35 bars).

2. The Riser Sleeve drill string spray washer, item number H-2-690134-14 (LMHC 1996), has an array of washer nozzles at the bottom to wash the drill string as it is pulled out of the tank after sampling is complete. The washing fluid for the riser sleeve washer has a maximum pressure of $1200 \mathrm{psig}$ ( 83 bars).

3. The Drill Rod Washer Manifold, item number H-2-690134-17 (LMHC 1996), washes the drill rod a second time as it is pulled out of the tank. (The drill rod may be washed twice since it was in direct contact with the waste and will be the most contaminated.) The washing fluid for the drill rod washer has a maximum pressure of $500 \mathrm{psig}$ ( 35 bars).

4. The Riser Sleeve Spray Washer, item number H-2-690134-15 (LMHC 1996), cleans the riser sleeve as it is taken out of the riser after sampling is complete. The washing fluid for the riser sleeve spray washer has a maximum pressure of $500 \mathrm{psig}$ ( 35 bars).

5. The Shielded Receiver Tube Spray Washer, item number H-2-690020-91 (LMHC 1994c), cleans the shielded receiver tube after the sampling operation is complete. The washing fluid for the shielded receiver tube spray washer has a maximum pressure of $500 \mathrm{psig}$ ( $35 \mathrm{bars}$ ).

\subsection{SCOPE}

This Engineering Task Plan addresses all activities associated with procurement and testing of a trailer-mounted spray wash system for core sampling operations. 


\subsection{DESCRIPTION}

\subsection{PHYSICAL DESCRIPTION}

\subsubsection{SPRAY WASH SYSTEM}

The spray wash system shall be a self contained, compact design and shall be trailer-mounted. The system shall include: the tank, electric motor driven pump, electrical switch gear, plumbing, and controls. The pump discharge shall be split into two spray wash supply lines--one high pressure supply line and one low pressure supply line. The high pressure supply line and low pressure supply line will each have its own hose reel. The pump shall be mounted in such a way that it will be easy to install and remove mechanical and electrical components. The trailer shall have a pintle trailer hitch with safety chains to be able to be towed by existing equipment.

\subsection{DESIGN REQUIREMENTS}

Design criteria shall be prepared and documented per RPP-PRO-1819 (LMHC 1998). The Design Compliance Matrix will be updated per Characterization Engineering Desk Instruction DI-CE-008-01 (Boger 1999a). The applicable Authorization Basis (AB) documents for the system are HNF-SD-WM-SAR-067 "TWRS Final Safety Analysis Report," (HNF 1999). HNF-SD-WM-TSR-006 (HNF 1999a) and WHC-SD-WM-SAD035, Rev.0-b (LMHC 1997).

The overall safety classification of the spray wash system is General Service (GS).

\subsubsection{INTERFACES}

3.2.1.1 Spray Washer Power Supply. The electrical power shall be compatible with the existing available electrical power: $240 \mathrm{VAC}, 60 \mathrm{Amp}$, single phase. The electrical connector shall be an RST-240/120-B HUBBELL 460B12W(male flanged inlet), $125 / 250 \mathrm{VAC}, 60 \mathrm{Amp}, 3 \mathrm{P}, 4 \mathrm{~W}$. The spray wash system is supplied with electrical power from an electrical distribution trailer (see drawings H-2-85340 [LMHC 1994] and $\mathrm{H}-2-85341$ [LMHC 1994a]).

3.2.1.2 The tank fill opening shall be accessible without the use of ladders or stairs.

3.2.1.3 The end of the 400-psig (28 bars) spray wash supply hose will have a 3/8 Hansen Socket Quick Connect series 3-HK Socket, part number LL3-H21.

3.2.1.4 The end of the 1200-psig (83 bars) spray wash supply hose will have a 3/8 Hansen Plug Quick Connect series 3-HK Plug, part number LL3-K21.

3.2.1.5 The trailer hitch will be $23 / 4$ inches $(7 \mathrm{~cm})$ minimum pintle hitch with safety chains.

\subsubsection{PERFORMANCE CHARACTERISTICS}

3.2.2.1 The trailer-mounted supply tank shall have a minimum capacity of 200 gallons (760 liters) and a maximum capacity of 300 gallons (1135 liters). The tank shall be 
made of a material compatible with the washing fluid, which is 0.3 molar Lithium Bromide (Libr) solution in water.

3.2.2.2 The pump discharge shall be divided into two spray wash supply lines.

3.2.2.3 A high pressure supply line shall supply $4 \mathrm{gpm}$ (15 liters/min) spray wash fluid adjustable from 0 psig ( 0 bar) to 1200 psig ( 83 bars).

3.2.2.4 A low pressure supply line shall supply $4 \mathrm{gpm}$ (15 liters) spray wash fluid adjustable from 0 psig ( 0 bar) to 400 psig. ( 28 bars).

3.2.2.5 Each spray wash line shall have a hose reel with 50 feet $(15.2 \mathrm{~m})$ of hose.

3.2.2.6 All wettable system components shall be made of a material compatible with 0.3 molar $\mathrm{LiBr}$. solution in water at $130^{\circ} \mathrm{F}\left(55^{\circ} \mathrm{C}\right)$.

3.2.2.7 The entire spray wash system shall be protected from freezing.

3.2.2.8 The tank shall be designed to be freeze and thaw resistant.

3.2.2.9 The system shall be capable of measuring the total volume of fluid used for washing.

3.2.2.10 The system shall be capable of supplying $130^{\circ} \mathrm{F}+/-10^{\circ} \mathrm{F}\left(55^{\circ} \mathrm{C}+/-5^{\circ} \mathrm{C}\right)$ spray wash fluid at a minimum ambient temperature of $20^{\circ} \mathrm{F}\left(-7^{\circ} \mathrm{C}\right)$, at $8 \mathrm{GPM}(30$ liters $/ \mathrm{min}$ ) continuously for 5 minutes and a minimum of 150 gallons per hour ( 570 liters/hour).

3.2.2.11 The system shall have a temperature indication of $+/-5^{\circ} \mathrm{F}\left(+/-3^{\circ} \mathrm{C}\right)$ for the spray wash fluid.

3.2.2.12 The system shall have maximum start up time of 4 hours.

3.2.2.13 When the trailer is not connected to a pulling vehicle, the trailer shall be stable when one $250 \mathrm{lbs}(115 \mathrm{~kg})$ person is walking anywhere on the trailer.

3.2.2.14 The applicable design standard for electrical equipment shall be NFPA 70, the National Electric Code.

\subsubsection{PHYSICAL CHARACTERISTICS}

3.2.3.1 All handles, switches, and connections that must be operated or mated in the field must be operable by a person wearing two pairs of size 10 leather gloves.

3.2.3.2 The trailer shall have a single axle.

3.2.3.3 The reels shall be self retracting fixed reels with a hose guide.

3.2.3.4 The tank shall be capable of being filled with 4-gallon (15 liter) bottles or a hose.

3.2.3.5 The system shall be able to be easily drained completely.

3.2.3.6 All gauges shall be oriented for ease of reading.

\subsubsection{RELIABILITY}

3.2.4.1 The spray wash system shall be capable of being operated for at least 2000 hours before requiring replacement. The system shall be capable of being started at least 5000 times. 


\subsubsection{MAINTAINABILITY}

3.2.5.1 All parts shall be readily accessible for field maintenance.

\subsubsection{ENVIRONMENT}

\subsubsection{Operational environment:}

3.2.6.2 The spray wash system shall operate reliably when exposed to summer heat $\left(110^{\circ} \mathrm{F}\right)$ $\left(44^{\circ} \mathrm{C}\right)$, intense direct sunlight , freezing rain, rain, snow, winter cold $\left(20^{\circ} \mathrm{F}\right)\left(-7^{\circ} \mathrm{C}\right)$ and high winds of $30 \mathrm{mph}$ ( $48 \mathrm{~km} /$ hour) and gusts up to $45 \mathrm{mph}$ ( $73 \mathrm{~km} / \mathrm{hour}$ ) with blowing dust.

\subsubsection{Storage environment:}

The components of the system shall be able to withstand storage temperature extremes from $-20^{\circ} \mathrm{F}\left(-29^{\circ} \mathrm{C}\right)$ to $140^{\circ} \mathrm{F}\left(60^{\circ} \mathrm{C}\right)$.

The system shall withstand severe weather including freezing rain, rain, snow, intense direct sunlight, winds to $70 \mathrm{mph}(113 \mathrm{~km} / \mathrm{hour})$, and blowing sand and dust.

\subsubsection{TRANSPORTABILITY}

3.2.7.1 The trailer shall be a compact design for optimum maneuverability.

3.2.7.2 The trailer shall meet all the applicable DOT requirements.

\subsection{ENGINEERING TASKS}

The engineering tasks contained in this task plan are the minimum necessary activities to provide a water supply system for the core sampling spray washers that is safe to deploy in the RPP tank farm facilities. The overall task is to procure and test a system that will meet the functions and requirements identified in this ETP. Characterization Engineering (CE) will complete the engineering tasks.

\subsubsection{DESIGN}

ECNs must be generated to accommodate necessary changes for the new system. The only anticipated ECNs relate to the Riser Sleeve hose quick connect.

\subsubsection{PROCEDURES}

Operation and maintenance procedures will be prepared and/or revised as required to support the operation and the maintenance of the new spray wash fluid supply system.

\subsubsection{SPARES}

A list of recommended spare parts will be provided for the spray wash fluid supply system. 


\subsection{DESIGN VERIFICATION}

Independent design verification will be performed in accordance with HNF-IP-0842, Volume IV, Section 4.24 "Design Verification" (LMHC 1998a). Design reviews will be conducted per LMH-PRO-1819 (LMHC 1998). The safety classification of the RMCS Support Trucks is General Service (GS).

\subsection{PROCUREMENT/FABRICATION TASKS}

Procurement activities will be performed by $\mathrm{CE}$.

\subsection{INSTALLATION TASKS}

The only installation task currently identified are the Hansen quick connect on the riser sleeve, assembly item number H-2-690134-14 (LMHC 1996), and the strainer assembly, item number H-2-690127-38 (LMHC 1994b).

\subsection{PRE-OPERATIONAL AND OPERATIONAL TESTS}

Testing will be documented and conducted per HNF-IP-0842, Volume IV, Section 4.28 "Testing Practices Requirements" (LMHC 1998a). An appropriate test/inspection report will be issued to document the results of acceptance and operational testing performed.

\subsection{ACCEPTANCE FOR BENEFICIAL USE}

An Acceptance for Beneficial Use (ABU) will be developed per HNF-IP-0842, Volume IV, Section 3.12, "Acceptance of Structures, Systems and Components for Beneficial Use" (LMHC 1998a), and Characterization Engineering Desk Instruction, DI-CP-004-02, "Acceptance for Beneficial Use (ABU)" (Boger 1999). The ABU is included as an Appendix to this ETP.

\subsection{RISK ASSESSMENT}

No potential risk can be identified to complete this task. Characterization Engineering and $\mathrm{CPO}$ are in concurrence to complete this task and the funding is available.

\subsection{ORGANIZATION}

\subsection{CHARACTERIZATION FIELD ENGINEERING (CFE)}

CFE will provide Cognizant Engineer support as required for this task. CFE will prepare or revise all operating and maintenance procedures, as required, to support the deployment of the new system.

Cognizant Manager: J. S. Schofield

Cognizant Engineer: R. N. Dale

\subsection{CHARACTERIZATION ENGINEERING}

CE will provide Design Authority support for this task. CE personnel will prepare all documentation associated with the development of the design requirements, procurement 
specifications, and fabrication and testing of the new system. CE personnel and the cognizant engineer will witness all testing, and the Design Authority will approve the results of all testing.

Design Authority: G. P. Janicek

Project Manager: J. D. Criddle Jr.

Responsible Engineer: C. G. Linschooten

\subsection{CHARACTERIZATION PROJECT OPERATIONS}

Characterization Project Operations (CPO) will provide review of specifications and procedures associated with this task. The logistics of performing on-site testing will be the responsibility of CPO with the support of CE/CFE.

Operations Manager: M. R. Kembel

Core Sampling Manager: J. S. Lee

\subsection{QUALITY ASSURANCE AND SAFETY}

CH2M HILL Hanford Group, Inc. (CHG) will provide Quality Assurance (QA) and Safety support

QA Engineer: M. L. McElroy

Safety Engineer: C. D. Jackson

\subsection{RADIATION ENGINEERING}

Not applicable.

\subsection{FLAMMABLE GAS EQUIPMENT ADVISORY BOARD}

Not applicable.

\subsection{SCHEDULE AND COST ESTIMATE}

The CE Project Manager will maintain a detailed schedule for all tasks. A rough schedule is included in Appendix A. The scheduled completion of this task will be affected by the priorities assigned by $\mathrm{CE}$ and $\mathrm{CPO}$ based upon project commitments.

Estimated Cost:
Engineering
350-hrs
Procurement
$\$ 50 \mathrm{k}$

Engineering expenses will be charged to Cost Account Charge Number (CACN)102250/Code of Accounts (COA) B000. Quality Assurance, Safety, and RADCON will also be charged to CACN 102250 for this task. CPO and maintenance expenses are funded separately. 


\subsection{CONFIGURATION MANAGEMENT}

A vendor information file will be established per LMH-PRO-1819 (LMHC 1998) to contain catalog cuts, performance specifications, and/or installation/operation instructions for components or systems supplied by the manufacturer. All modifications made to standard manufacturer products will be documented on $\mathrm{H}-2$ series drawings.

\subsection{QUALITY ASSURANCE}

All work associated with this task will be in compliance with HNF-IP-0842, Volume XI, Quality Assurance Program, Section 1.1. (LMHC 19989a). QA oversight will be provided as defined in this ETP. QA will participate in the review of design, specification, and testing documents, witness testing as specified in the test procedures, and approve test results.

\subsection{SAFETY AND AUTHORIZATION BASIS}

All work associated with this task will be in compliance with HNF-IP-0842, Volume IX, Section 1.1,"RPP Safety Program Plan" (LMHC 1998). Safety will participate in the review of design, specification, and testing documents.

The AB for the system will be HNF-SD-WM-SAR-067, "TWRS Final Safety Analysis Report" (HNF 1999), HNF-SD-WM-TSR-006 (HNF 1999a), and WHC-SD-WM-SAD-035 (LMHC 1997). The applicable industry safety standards will be considered for all safety concerns associated with this task. The Unreviewed Safety Question (USQ) process will be used as required per HNF-IP-0842, Volume IV, Section 5.4, "Unreviewed Safety Questions" (LMHC-1998a).

\subsection{SYSTEMS ENGINEERING}

This activity is necessary to support the characterization of the waste in the underground waste storage tanks on the Hanford Site. This activity supports the Tank Farms task identified in the Work Breakdown Structure (WBS) as task number 1.1.1.1.1.3.1.9, Core Sampling Systems.

\subsection{CLOSEOUT COSTS}

If the task is no longer required, an estimate will be prepared before the task is closed. The amounts of all outstanding purchase agreements will be included as closeout costs. 
RPP-6134

Rev.0

\subsection{REFERENCES}

Boger, R. M., 1999, “Acceptance for Beneficial Use (ABU)," Characterization Engineering Desk Instruction, DI-CP-004-02, Lockheed Martin Hanford Corporation, Richland, Washington.

Boger, R. M., 1999a, "Design Compliance Matrix," Characterization Engineering Desk Instruction, DI-CE-008-01.

HNF, 1999, HNF-SD-WM-SAR-067, Rev. 1C, "Tank Waste Remediation System Final Safety Analysis Report"(FSAR), January 1999, Lockheed Martin Hanford Corporation, Richland, Washington.

HNF, 1999a, HNF-SD-WM-TSR-006, Rev. 1B, “Tank Waste Remediation System Technical Safety Requirements," including Addendum, January 1999, Lockheed Martin Hanford Corporation, Richland, Washington.

LMHC, 1994, Drawing H-2-85340, Rev. 2, "Core Sampling Trailer One Line Diagrams," Lockheed Martin Hanford Corporation, Richland, Washington.

LMHC, 1994a, Drawing H-2-85341, Rev. 1, "Core Sampling Trailer DT-B - Electrical," Lockheed Martin Hanford Corporation, Richland, Washington.

LMHC, 1994b, Drawing H-2-690127, Rev. 2, "Core Sampling Misc. Equipment," Lockheed Martin Hanford Corporation, Richland, Washington.

LMHC, 1994c, Drawing H-2-690020, Rev. 3, "Shielded Receiver Assembly (RMCST)," Lockheed Martin Hanford Corporation, Richland, Washington.

LMHC, 1996, Drawing H-2-690134, Rev. 5 "Drill String Arrangements (RMCST)," Lockheed Martin Hanford Corporation, Richland, Washington.

LMHC, 1997, WHC-SD-WM-SAD-035, Rev. 0-b, "A Safety Assessment of Rotary-Mode Core Sampling in Flammable-Gas Single-Shell Tanks: Hanford Site, Richland, Washington, August 1997," Lockheed Martin Hanford Corporation, Richland, Washington.

LMHC, 1998, LMH-PRO-1819, latest revision, "Project Hanford Policy and Procedure System PHMC Engineering Requirements," Lockheed Martin Hanford Corporation, Richland, Washington.

LMHC, 1998a, HNF-IP-0842, "RPP Administration (Procedures, Policies, Plans and Waivers)," latest revision, Lockheed Martin Hanford Corporation, Richland, Washington. 
RPP-6134

Rev.0

Appendix A. Schedule 


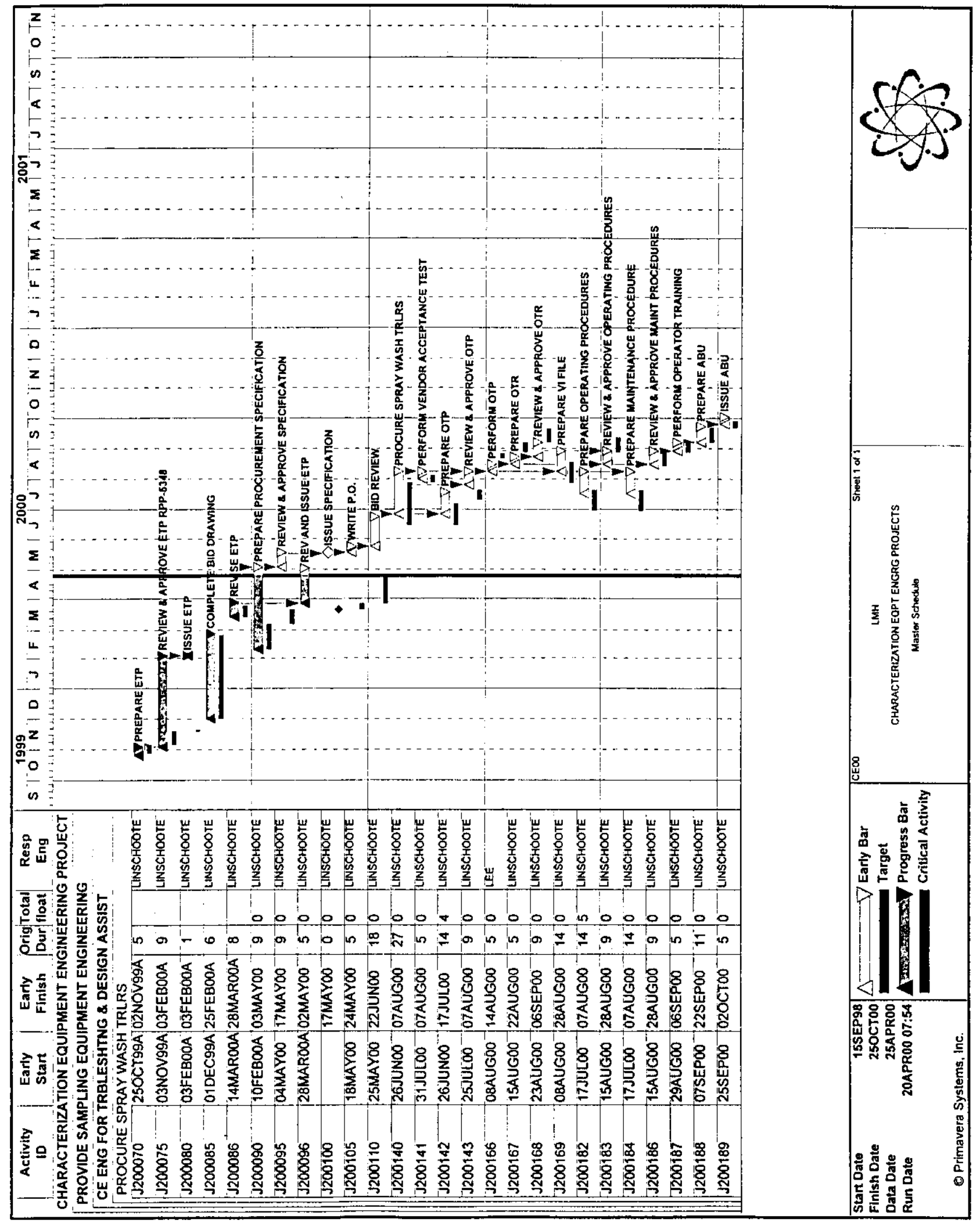


RPP-6134

Rev.0

\section{Appendix B. Cold Weather Operating Parameters and Design Considerations.}

Considered is an 80 -gallon tank made of $1 / 8$-inch-thick stainless steel plate with no insulation. The hose is to be $1 / 2$-inch I.D, 50 feet long, not considering the rubber on the hose.

Preliminary calculations indicate that, when electrical power is disconnected from the spray wash fluid supply system, the water is at $130^{\circ} \mathrm{F}$ in the tank, and the outside temperature is $0^{\circ} \mathrm{F}$, it takes approximately two days for the water to cool to $32^{\circ} \mathrm{F}$ and another four days to freeze solid in the tank. Hoses filled with $130^{\circ} \mathrm{F}$ water will most likely freeze solid in 8 to 12 hours. Therefore, all the hoses and the pump should be blown out after every shift, and the tank should be emptied when the tank is exposed to freezing conditions for longer than 3 days.

The tank and pump can be insulated with PVC foam panels to slow this process. The heater in the tank can be wired to accept 110 VAC. Powered by $110 \mathrm{VAC}$ the heater puts out approximately 1900 watts and will keep the tank warm as long as the electric power is on and there is insulation. Alternately the tank and the pump can be heat traced to prevent freezing, which also requires electric power.

If the tank freezes solid, it is probable that the heater will be damaged. If the pump freezes, it will probably be ruined. If the hoses freeze, the integrity of the hoses might be lost. 
RPP-6134

Rev.0

Appendix C. Acceptance for Beneficial Use 


\begin{tabular}{|c|c|c|c|}
\hline \multicolumn{4}{|c|}{$\begin{array}{c}\text { DOCUMENTATION REQUIRED from } \\
\text { Project WATER SUPPIY · FOR RMCS SPRAY WASH TRAILER } \\
\text { Prior to ACCEPTANCE FOR BENEFICIAL USE }\end{array}$} \\
\hline DESCRIPTION & RESPONSIBILITY & DESCRIPTION & RESPONSIBILITY \\
\hline 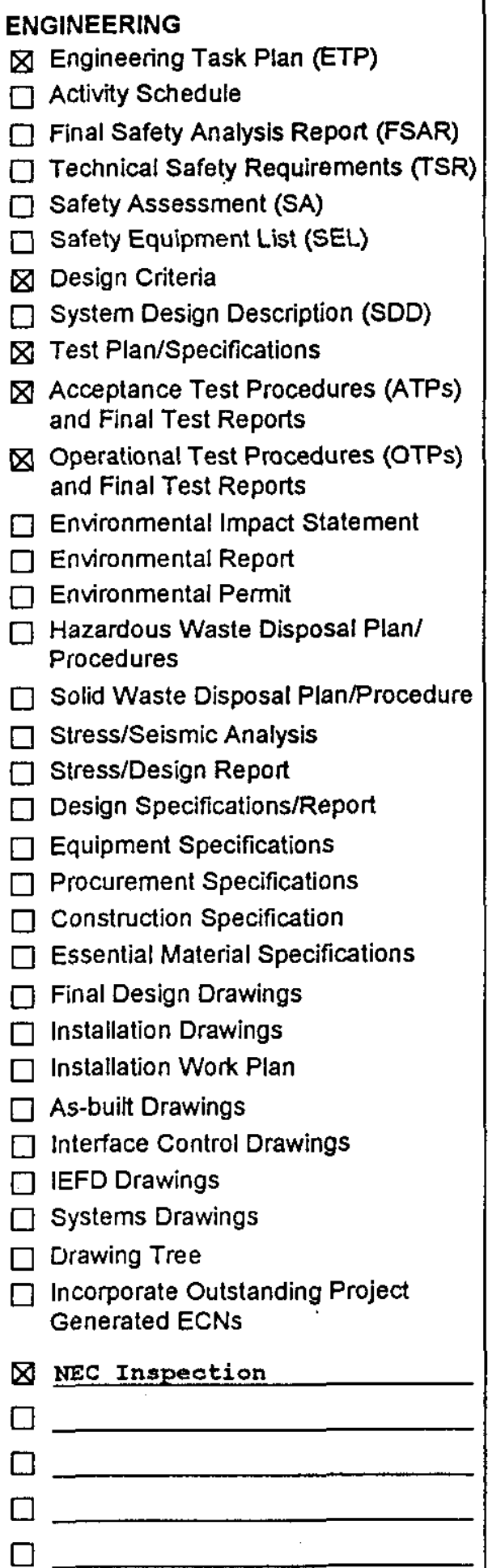 & $\begin{array}{l}\text { CG LINSCHOOTEN } \\
\text { N/A } \\
\text { N/A } \\
\text { N/A } \\
\text { N/A } \\
\text { N/A } \\
\text { CG IINSCHOOTEN } \\
\text { N/A } \\
\text { CG LINSCHOOTEN } \\
\text { CG LINSCHOOTEN } \\
\text { CG IINSCHOOTEN } \\
\text { N/A } \\
\text { N/A } \\
\text { N/A } \\
\text { N/A } \\
\text { N/A } \\
\text { N/A } \\
\text { N/A } \\
\text { N/A } \\
\text { N/A } \\
\text { N/A } \\
\text { N/A } \\
\text { N/A } \\
\text { N/A } \\
\text { N/A } \\
\text { N/A } \\
\text { N/A } \\
\text { N/A } \\
\text { N/A } \\
\text { N/A } \\
\text { N/A } \\
\text { N/A } \\
\text { CG LINSCHOOTEN }\end{array}$ & 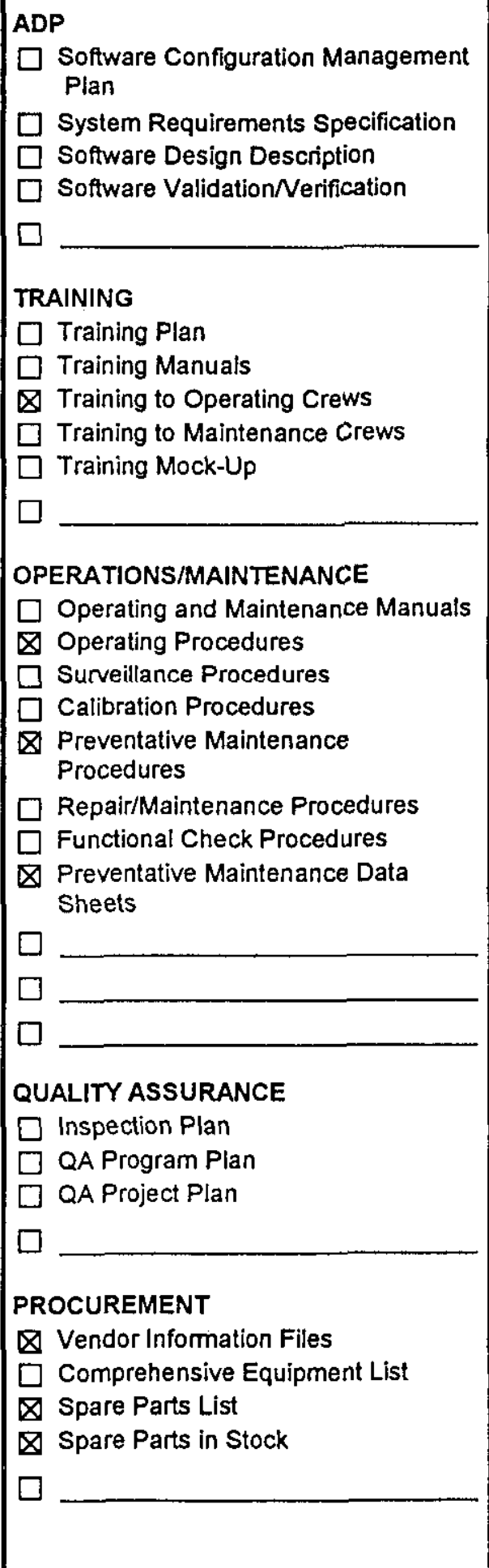 & $\begin{array}{l}\text { N/A } \\
\text { RN DALE } \\
\text { N/A } \\
\text { N/A } \\
\text { RN DALE } \\
\text { N/A } \\
\text { N/A } \\
\text { RN DALE }\end{array}$ \\
\hline
\end{tabular}

